\title{
Weed management and its relation to yield and seed physiological potential in common bean cultivars ${ }^{1}$
}

\author{
Denis Santiago da $\operatorname{Costa}^{2}$, Rafael Marani Barbosa ${ }^{3}$, Marco Eustáquio de $\mathrm{Sá}^{4}$
}

\section{RESUMO}

Manejo de plantas daninhas e sua relação com a produtividade e potencial fisiológico de sementes de feijoeiro

O feijão é uma importante cultura para o Brasil, devido, principalmente, às suas características nutricionais. Para o cultivo, alguns tratos culturais, como o manejo de plantas daninhas, são fundamentais para gerar altas produtividades. Entretanto, estudos têm demonstrado que o manejo de plantas daninhas pode ser alterado, em função do ciclo da cultura. Assim, este estudo objetivou identificar o melhor estádio fenológico em cultivares precoces de feijoeiro, para realizar o controle de plantas daninhas sem que a competição promova redução de produtividade e qualidade de sementes. $\mathrm{O}$ experimento foi realizado em blocos casualizados, com 20 tratamentos e quatro repetições, em esquema fatorial $2 \times 2 \times 5$ (cultivares $\times$ tipos de controle $\times$ épocas de controle). Para cada cultivar (Carioca Precoce e IPR-Colibri), os tratamentos consistiram do controle de plantas daninhas durante todo o ciclo e no estádio $\mathrm{V}_{4-3}$ (primeiros três nós no ramo principal, com folhas trifolioladas), $\mathrm{R}_{5}$ (aparecimento de botões florais) e $\mathrm{R}_{8}$ (aparecimento de vagens) e ciclo completo sem controle de plantas daninhas. Os tipos de controle foram o químico (fluazifop-p-butil + fomesafen) e o mecânico (enxada). A cultivar Carioca Precoce apresentou melhor desempenho agronômico e produtivo que a IPR-Colibri, no entanto, suas sementes apresentaram menor vigor. As características agronômicas, rendimento e potencial fisiológico das sementes não foram afetados pelo tipo de controle (químico ou mecânico). $\mathrm{O}$ período ideal para controlar plantas daninhas em cultivares precoces de feijão e obter o melhor rendimento e potencial fisiológico das sementes foi observado no estádio fenológico $V_{4-3}$.

PALAVRAS-CHAVE: Phaseolus vulgaris L.; competição com plantas daninhas; vigor de sementes.

\section{INTRODUCTION}

In Brazil, studies investigating the coexistence of weeds with common bean (Phaseolus vulgaris L.)

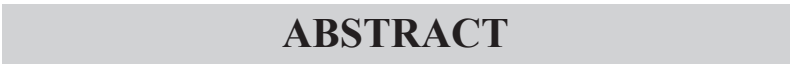

Common bean is an important crop in Brazil primarily because of its nutritional characteristics. Some agronomic practices, such as weed management, are fundamental to cultivation, as a means of obtaining a high crop yield. However, some studies have shown that weed management may alter the function of the cultivar cycle. Thus, this study aimed at determining the optimal phenological stage in early-maturing common bean cultivars to perform the weed control without providing reductions in yield and seed quality. The experimental design was randomized blocks with 20 treatments and four replications, in a $2 \times 2 \times 5$ (cultivars $\times$ types of weed control $\times$ periods of weed control) factorial scheme. The periods of weed control for both cultivars (Carioca Precoce and IPR-Colibri) consisted of full cycle weeded (control), weed control at the $\mathrm{V}_{4-3}$ stage (first three nodes on the main stem with trifoliate leaves), at the $\mathrm{R}_{5}$ stage (beginning of bloom) and at the $\mathrm{R}_{8}$ stage (appearance of pods) and full cycle unweeded (no weed control). The types of weed control used were chemical (fluazifop-p-butyl + fomesafen) and mechanical (hoe). The Carioca Precoce cultivar demonstrated higher agronomic performance and yield than the IPR-Colibri cultivar, although the IPR-Colibri seeds had a higher vigor. The type of weed control (chemical or mechanical) did not affect the agronomic characteristics, yield and seed physiological potential of the cultivars. The ideal period for weed control in early-maturing common bean cultivars to obtain a higher yield and seed physiological potential was observed at the $\mathrm{V}_{4-3}$ phenological stage.

KEY-WORDS: Phaseolus vulgaris L.; weed competition; seed vigor.

are particularly important because this species of bean can be cultivated throughout the year, for three seasons (wet, dry and irrigated). This large sowing window can intensify or reduce competition with

1. Article received in Apr./2012 and accepted for publication in Apr./2013 (Registration number: PAT 17807).

2. Universidade de São Paulo (USP), Escola Superior de Agricultura “Luiz de Queiroz”, Departamento de Produção Vegetal, Piracicaba, SP, Brazil. E-mail: denis.esalq@gmail.com.

3. Universidade Estadual Paulista (Unesp), Faculdade de Ciências Agrárias e Veterinárias, Departamento de Produção Vegetal, Jaboticabal, SP, Brazil. E-mail: rmarani@gmail.com.

4. Universidade Estadual Paulista (Unesp), Faculdade de Engenharia, Departamento de Fitotecnia, Tecnologia de Alimentos e Socioeconomia, Ilha Solteira, SP, Brazil.E-mail:mesa@agr.feis.unesp.br. 
weeds, as there are differences in temperature, water availability, nutrients, luminosity and weed type, for each season.

In general, the critical period for preventing weed interference in common bean cultivation occurs between 10 and 35 days after emergence (DAE) (Ferreira et al. 2006) or during the phenological stage, which takes place between the $\mathrm{V}_{1}$ (seedling emergence) and $\mathrm{R}_{6}$ (full bloom) stages (Kozlowski et al. 2002). During the plant development, common bean plants should not coexist with weeds because there can be yield losses of up to 52\% (Christoffoleti et al. 2005).

Recently, Borchartt et al. (2011) indicated that the period for preventing competition can be different among early-maturing common bean cultivars. The authors demonstrated that the critical period (4 to 18 days after emergence) for the early-maturing Carioca Precoce cultivar was shorter than the one observed for late-maturing cultivars. Additionally, Cury et al. (2013) reported that IPR-Colibri, another early-maturing cultivar, was less tolerant to weed competition than two other common bean cultivars.

These recent approach about weed competition and early-maturing common bean cultivars provides important information about the cultivation of this species. Plant development occurs more quickly in early-maturing common bean cultivars than in late-maturing common bean cultivars. As a result, a mistake in agronomic practices may create a yield reduction because the plant does not have enough time to recover the loss.

In addition to the effects on yield (Kozlowski et al. 2002, Salgado et al. 2007, Scholten et al. 2011), weed growth may influence the physiological potential of the seed. This is due to a stronger competition, with fundamental factors that alter the seed quality, such as soil fertility (Nakagawa et al. 2004) and water availability (Crusciol et al. 2001).

A close understanding of weed management is essential for obtaining higher crop yields and preserving seeds quality. Thus, this study aimed at determining the optimal phenological stage in common bean cultivars to perform the weed control without providing reductions in yield and seed quality.

\section{MATERIAL AND METHODS}

This study was conducted in Selvíria, Mato Grosso do Sul State, Brazil (20³4'S, 5040'W and $335 \mathrm{~m}$ above sea level), and in Ilha Solteira, São Paulo State, Brazil (20 $41^{\prime} \mathrm{S}, 51^{\circ} 34^{\prime} \mathrm{W}$ and $335 \mathrm{~m}$ above sea level). The soil in the experimental area was classified as a "Typic Acrustox Oxisol" (SSS 2010), corresponding to a "Latossolo Vermelho distrófico", according to the Brazilian Soil Classification System (Embrapa 2006). The climate is classified as "Aw", after Köppen's climate classification, with a mean annual temperature of $24.5^{\circ} \mathrm{C}$, annual rainfall of $1,232 \mathrm{~mm}$ and relative air humidity of $64.8 \%$ (Hernandez et al. 1995).

The seedbed preparation consisted of one plowing and two harrowings (with the first harrowing after the plowing and the second harrowing prior to the sowing), leaving the soil devoid of weeds. The fertilizer addition was calculated based on the results of a soil analysis (Table 1) and the recommendation for the common bean (Ambrosano et al. 1997). Fertilizer was applied to all treatments using $20 \mathrm{~kg} \mathrm{ha}^{-1}$ of nitrogen, $70 \mathrm{~kg} \mathrm{ha}^{-1}$ of phosphorus $\left(\mathrm{P}_{2} \mathrm{O}_{5}\right)$ and $40 \mathrm{~kg} \mathrm{ha}^{-1}$ of potassium $\left(\mathrm{K}_{2} \mathrm{O}\right)$. Additionally, the nitrogen was applied at the $\mathrm{V}_{4-4}$ stage (first four nodes on the main stem with trifoliate leaves), at a rate of $80 \mathrm{~kg} \mathrm{ha}^{-1}$.

The early-maturing cultivars used in this study were Carioca Precoce and IPR-Colibri, both type I (erect plants). On May 13, 2009 (irrigated season), the seeds were sown mechanically at 15 seeds $\mathrm{m}^{-1}$, for a final density of 12 plants $\mathrm{m}^{-1}$, with an inter-row spacing of $0.5 \mathrm{~m}$, to obtain a final plant population of 240,000 plants ha-1.

Before sowing, the seeds were treated with a fungicide mixture of carboxin + thiram, at the rate of $50 \mathrm{~g}+50 \mathrm{~g}$ of active ingredient (a.i.) per $100 \mathrm{~kg}$ of seeds. The insecticides methamidophos, triazophos + deltamethrin and chlorpyriphos, respectively at the

Table 1. Chemical soil analysis of the experimental area (Selvíria, MS, 2009).

\begin{tabular}{cccccccc}
\hline $\mathrm{pH}$ & $\mathrm{P}_{\text {resin }}$ & Organic matter & $\mathrm{K}$ & $\mathrm{Ca}$ & $\mathrm{Mg}$ & Potential acidity (H+Al) & Base saturation $(\mathrm{V})$ \\
\cline { 2 - 5 } $\mathrm{CaCl}_{2}$ & $\mathrm{mg} \mathrm{dm}^{-3}$ & $\mathrm{~g} \mathrm{dm}^{-3}$ & & & & $\mathrm{cmol}_{\mathrm{c}} \mathrm{dm}^{-3}$ & \\
\hline 5.1 & 20 & 24 & 0.27 & 1.7 & 1.4 & 2.8 & 55 \\
\hline
\end{tabular}


rates of $300 \mathrm{~g}$ of a.i. ha ${ }^{-1}, 262.5+7.5 \mathrm{~g}$ of a.i. ha ${ }^{-1}$ and $480 \mathrm{~g}$ of a.i. ha ${ }^{-1}$, were used to control the main pests, during plant development. Fungal diseases were controlled at the $\mathrm{R}_{5}$ stage by preventive spraying of mancozeb at a rate of $1.6 \mathrm{~kg}$ of a.i. $\mathrm{ha}^{-1}$. The common bean plants were irrigated every three days or according to the evapotranspiration of the area using an aspersion system with sprinklers.

The experiment was conducted as a completely randomized blocks design (CRBD), in a $2 \times 2 \times 5$ (cultivars $\times$ types of weed control $\times$ periods of weed control) factorial scheme, with 20 treatments and four replications, consisting of two cultivars (Carioca Precoce and IPR-Colibri), two types of weed control (chemical - application of fluazifop-p-butyl + fomesafen $\left(200+250 \mathrm{~g}\right.$ of a.i. ha $\left.{ }^{-1}\right)$ with backpack sprayer $(20 \mathrm{~L}$, piston type pump, even flat-fan nozzle 110.01, flow $100 \mathrm{~L} \mathrm{ha}^{-1}$ ) and mechanical - hoe) and five periods of weed control (full cycle weeded - control; weed control at the $\mathrm{V}_{4-3}$ stage - first three nodes on the main stem with trifoliate leaves, identified at $15 \mathrm{DAE}$; weed control at the $\mathrm{R}_{5}$ stage - beginning of bloom, identified at $30 \mathrm{DAE}$; weed control at the $\mathrm{R}_{8}$ stage - appearance of pods, identified at 45 DAE; and full cycle unweeded (no weed control). The plots consisted of six $5.0 \mathrm{~m}$ long rows, with $0.5 \mathrm{~m}$ between rows and an evaluation area of $6.0 \mathrm{~m}^{2}$.

During plant development, weed identification and evaluation were performed by randomly placing a $1.0 \mathrm{~m}^{2}$ metal frame in each plot and identifying the weeds that were present within the frame. The weeds were identified according to Lorenzi (2006). At the end of the crop cycle, ten common bean plants were randomly selected from each plot to assess various agronomic characteristics (plant height, first pod height, number of pods per plant, number of seeds per plant, number of seeds per pod and 100-seeds weight).

The yield was obtained by harvesting the plants from the evaluation area of each plot. After drying, the plants were threshed, the seeds weighed and the moisture content was determined. The moisture content was corrected to $13 \%$ (wet basis) to eliminate differences in moisture content from the yield. The relative yield was calculated by comparing the yields of the weeded group to the full cycle unweeded group.

Seed quality was evaluated by several means. Seed moisture content was assessed using two samples of $10 \pm 1 \mathrm{~g}$ of seeds each, which were weighed on a precision analytical balance $(0.001 \mathrm{~g})$ and dehydrated by the oven method at $105 \pm 3^{\circ} \mathrm{C}$, for 24 hours. After drying, the seeds samples were weighed again, thus allowing the moisture content to be calculated on a wet basis (Brasil 2009).

Germination was determined by randomly selecting 200 seeds from each treatment, which were then divided into four replications of 50 seeds each. The seeds of each replication were placed on two sheets of towel paper and covered with another sheet of the same paper that had been moistened with distilled water in an amount equivalent to 2.5 times the mass of the dry substrate. The towels were rolled and placed in a seed germinator at $25^{\circ} \mathrm{C}$. Assessments were performed five and seven days after the beginning of the germination test (Brasil 2009). After the first and second count, the germination speed index was calculated (Maguire 1962).

Seed vigor was evaluated using accelerated ageing and electrical conductivity tests. Accelerated ageing was determined by assessing four replications of 50 seeds each, which were evenly distributed in a single layer on top of a stainless steel screen. This screen was placed in the upper part of $11.0 \mathrm{~cm} \times 11.0 \mathrm{~cm} \times$ $3.0 \mathrm{~cm}$ transparent plastic boxes that contained $40.0 \mathrm{~mL}$ of distilled water in the bottom. The boxes were closed and placed in a seed germinator at $41^{\circ} \mathrm{C}$, for 72 hours (Baalbaki et al. 2009). The seeds were evaluated by the germination test, as previously described. Evaluations were made together with the first germination count test, on the fifth day after the test began (Brasil 2009). Electrical conductivity was assessed using four replications of 50 seeds each. After drying, the seeds were immersed in plastic cups containing $75.0 \mathrm{~mL}$ of distilled water and maintained in an incubation chamber at $25^{\circ} \mathrm{C}$, for 24 hours (Vieira \& Krzyzanowski 1999). The electrical conductivity of the solution was determined and the results were expressed in $\mu \mathrm{S} \mathrm{cm}^{-1} \mathrm{~g}^{-1}$.

The data were analyzed to determine the normality of the distribution, in addition to assessing the uniformity of the variance. An analysis of variance (Anova) was conducted to determine the significance of the data. When the $\mathrm{F}$ value was significant at $5 \%$ or $1 \%(\mathrm{p}<0.05$ or $\mathrm{p}<0.01)$, the means were compared using the Tukey test, at $5 \%$. The software used was Sisvar (Ferreira 2008).

\section{RESULTS AND DISCUSSION}

Seedling emergence began five days after sowing, for both common bean cultivars. The 
total plant cycle was 66 days for IPR-Colibri and 70 days for Carioca Precoce. The main weeds present in the experimental area were Panicum maximum Jacq., Euphorbia heterophylla L., Ipomoea purpurea (L.) Roth, Alternanthera tenella Colla, Commelina benghalensis L., Amaranthus spp., Lolium multiflorum Lam., Ricinus communis L., Portulaca oleracea L., Desmodium tortuosum (Sw.) DC., Urochloa spp., Bidens pilosa L. and Sorghum halepense (L.) Pers. The mean weed population was 124 weeds $\mathrm{m}^{-2}$, with the maximum and minimum values being 184 weeds $\mathrm{m}^{-2}$ and 90 weeds $\mathrm{m}^{-2}$, respectively, in unweeded plots.

The weed population observed was considered to have the potential to reduce yield because, although there is no exact minimum number for a weed population that indicates it will cause interference in common bean plants, it is known that the more numerous the weed population, the greater the competition for resources. As a result, there is more intense competition with the crop. Furthermore, the weed population in this study was similar to those of other studies examining weed interference in common beans, where a crop yield reduction was observed (Salgado et al. 2007, Pereira et al. 2012).

The herbicide mixture of fluazifop-pbutyl + fomesafen did not reduce the agronomic characteristics and yield, when compared to the mechanical control, indicating that both types of control may be used (Tables 2, 3 and 4). Regarding herbicide management, the weed control with fluazifop-p-butyl + fomesafen was more efficient at the first phenological stage of weed, when the weeds were seedlings. This weed stage was identified at the $\mathrm{V}_{3}$ and $\mathrm{V}_{4-3}$ stages of common bean. For mechanical control, all periods of weed control were efficient.

All the parameters evaluated for agronomic characteristics were significantly different at $5 \%$, for both cultivars (Tables 2 and 3). The Carioca Precoce cultivar had a lower final plant population than the IPR-Colibri cultivar (Table 2), despite the correction for seed density based on the germination results. The Carioca Precoce seeds may have had a lower physiological potential (vigor), which may have influenced the final population, even though cultivation was conducted with an appropriate stand (approximately 250,000 plants ha-1).

The period of coexistence with weeds negatively influenced the final stand, even with mechanized sowing providing a similar initial plant
Table 2. Final plant population (FP), plant height $(\mathrm{H})$ and first pod height (FPH) obtained from two cultivars, with different types and periods of weed control (Selvíria, MS, 2009).

\begin{tabular}{|c|c|c|c|}
\hline \multirow{2}{*}{ Treatment } & FP & FPH & $\mathrm{H}$ \\
\hline & plants ha ${ }^{-1}$ & \multicolumn{2}{|c|}{$\mathrm{cm}$} \\
\hline \multicolumn{4}{|l|}{ Cultivars (Cu) } \\
\hline Carioca Precoce & $234,333 b^{1}$ & $20.4 \mathrm{a}^{1}$ & $58.7 \mathrm{a}^{1}$ \\
\hline IPR-Colibri & $251,111 \mathrm{a}$ & $16.3 \mathrm{~b}$ & $46.2 \mathrm{~b}$ \\
\hline \multicolumn{4}{|l|}{ Types of weed control (Co) } \\
\hline Chemical & 243,000 & 18.8 & 52.1 \\
\hline Mechanic & 242,444 & 17.9 & 52.7 \\
\hline \multicolumn{4}{|l|}{ Periods of weed control (T) } \\
\hline Full cycle weeded (control) & $259,444 \mathrm{a}^{1}$ & $17.0 \mathrm{a}^{1}$ & $55.5 \mathrm{a}^{1}$ \\
\hline $\mathrm{V}_{4-3}$ & $255,278 \mathrm{a}$ & $17.7 \mathrm{ab}$ & $53.3 \mathrm{ab}$ \\
\hline $\mathrm{R}_{5}^{4-3}$ & $242,778 \mathrm{ab}$ & $18.6 \mathrm{ab}$ & $51.0 \mathrm{~b}$ \\
\hline $\mathrm{R}_{8}$ & $236,111 \mathrm{ab}$ & $18.6 \mathrm{ab}$ & $51.0 \mathrm{~b}$ \\
\hline $\begin{array}{l}\text { Full cycle unweeded (no } \\
\text { weed control) }\end{array}$ & $220,000 \mathrm{~b}$ & $19.8 \mathrm{~b}$ & $51.4 \mathrm{~b}$ \\
\hline \multicolumn{4}{|l|}{ Statistical probability* } \\
\hline $\mathrm{Cu}$ & $\mathrm{p} \leq 0.01$ & $\mathrm{p} \leq 0.01$ & $\mathrm{p} \leq 0.01$ \\
\hline Co & $p>0.05$ & $p>0.05$ & $p>0.05$ \\
\hline $\mathrm{T}$ & $\mathrm{p} \leq 0.05$ & $\mathrm{p} \leq 0.05$ & $\mathrm{p} \leq 0.05$ \\
\hline $\mathrm{Cu} \times \mathrm{Co}$ & $\mathrm{p}>0.05$ & $\mathrm{p}>0.05$ & $\mathrm{p}>0.05$ \\
\hline $\mathrm{Cu} \times \mathrm{T}$ & $\mathrm{p}>0.05$ & $\mathrm{p}>0.05$ & $\mathrm{p}>0.05$ \\
\hline $\mathrm{Co} \times \mathrm{T}$ & $\mathrm{p}>0.05$ & $\mathrm{p}>0.05$ & $\mathrm{p}>0.05$ \\
\hline $\mathrm{Cu} \times \mathrm{Co} \times \mathrm{T}$ & $\mathrm{p}>0.05$ & $\mathrm{p}>0.05$ & $\mathrm{p}>0.05$ \\
\hline CV (\%) & 11.5 & 14.1 & 7.4 \\
\hline
\end{tabular}

population in the plots. In the full cycle weeded (control), the common bean plants were able to maintain a higher population than when other treatments were assessed (Table 2). This suggests that the common bean plant is significantly affected by weed competition, which causes plant suppression during the crop cycle. Additionally, a lower population of common bean plants was observed in full cycle unweeded (no control).

Radosevich \& Holt (1984) reported that the higher the weed density and coexistence, the greater the competition between weeds and crops, which increases plant mortality. This result was observed in the present study, as spaces were found in the full cycle unweeded (no weed control) at the end of the crop cycle that should have common bean plants, indicating that the plants had died.

The plant and first pod height observed for the Carioca Precoce cultivar were higher than those of the IPR-Colibri (Table 2). The common bean height decreased with the increase in weed coexistence (Table 2). The treatments with later weed control (no 
control, control at the $\mathrm{R}_{8}$ and $\mathrm{R}_{5}$ stages) resulted in shorter common bean plants, when compared with the full cycle weeded (control). The first pod height was higher for the greater weed coexistence, due to the increased incidence of pod abortion observed on the lower part of the plants (Table 2).

The lower plant height and the higher first pod height in the treatment with later weed control demonstrated that coexistence does not allow for normal development of common bean plants, primarily due to competition with weeds in the area. This fact is clearly observed in intra-specific competition, where the competition for resources results in shorter plant heights (Jadoski et al. 2000). In the case of inter-specific competition (crop-weed), this decrease of plant height may be compounded, because several species coexist in the same area and the requirements in nutrients and exploring in soil depths are different.

The number of pods per plant, seeds per plant and seeds per pod, 100-seeds weight and yield were higher for the Carioca Precoce cultivar than for the IPR-Colibri (Table 3). The yield results obtained for each cultivar in this study support the yield estimates published in the cultivar catalogues, as for IPR-Colibri the yield potential is $3,971 \mathrm{~kg} \mathrm{ha}^{-1}$, with a real average of 2,262 $\mathrm{kg} \mathrm{ha}^{-1}$ (Iapar 2004). For the Carioca Precoce, the yield potential is approximately 2,750 kg ha-1 (CATI 1997).

The period of weed control was the main factor that influenced the number of pods per plant, number of seeds per plant and yield (Table 3). Full cycle weeded (control) and weed control at the $\mathrm{V}_{4-3}$ stage resulted in higher numbers of pods per plant than the control at the $\mathrm{R}_{8}$ stage. Results for control at the $\mathrm{R}_{5}$ stage were similar to the other treatments. Thus, the longer coexistence period with weeds (no control and control at the $\mathrm{R}_{8}$ stage) resulted in a lower ability of the common bean to develop more pods, probably due to weed interference with nutrients, water and light uptake. The number of seeds per plant was influenced by a higher number of pods per plant, as the number of seeds per pod was not significant at $5 \%$. For 100 -seeds weight, no differences were observed between the periods of weed control, demonstrating that weed competition mainly affects

Table 3. Number of pods per plant (NPPl), number of seeds per plant (NSPl), number of seeds per pod (NSPo), 100-seeds weight (W100), yield (Y) and relative yield (RY) obtained from two cultivars, with different types and periods of weed control (Selvíria, MS, 2009).

\begin{tabular}{|c|c|c|c|c|c|c|}
\hline \multirow{2}{*}{ Treatment } & \multirow{2}{*}{ NPP1 } & \multirow{2}{*}{ NSP1 } & \multirow{2}{*}{ NSPo } & W100 & $\mathrm{Y}$ & RY \\
\hline & & & & $\mathrm{g}$ & $\mathrm{kg} \mathrm{ha}^{-1}$ & $\%$ \\
\hline \multicolumn{7}{|l|}{ Cultivars (Cu) } \\
\hline Carioca Precoce & $10.3 \mathrm{a}^{1}$ & $48.8 \mathrm{a}^{1}$ & $4.7 \mathrm{a}^{1}$ & $23.6 \mathrm{a}^{1}$ & $2,727 \mathrm{a}^{1}$ & - \\
\hline IPR-Colibri & $9.2 \mathrm{~b}$ & $39.8 \mathrm{~b}$ & $4.3 \mathrm{~b}$ & $23.2 \mathrm{~b}$ & $2,357 \mathrm{~b}$ & - \\
\hline \multicolumn{7}{|l|}{ Types of weed control (Co) } \\
\hline Chemical & 9.5 & 42.8 & 4.4 & 23.3 & 2,445 & - \\
\hline Mechanic & 10.0 & 45.8 & 4.5 & 23.5 & 2,639 & - \\
\hline \multicolumn{7}{|l|}{ Periods of weed control (T) } \\
\hline Full cycle weeded (control) & $11.2 \mathrm{a}^{1}$ & $52.2 \mathrm{a}^{1}$ & 4.6 & 23.5 & $3,208 \mathrm{a}^{1}$ & 70 \\
\hline $\mathrm{V}_{4-3}$ & $11.4 \mathrm{a}$ & $51.5 \mathrm{a}$ & 4.5 & 23.7 & $3,138 \mathrm{a}$ & 66 \\
\hline $\mathrm{R}_{5}$ & $9.7 \mathrm{ab}$ & $43.4 \mathrm{ab}$ & 4.4 & 23.3 & $2,406 \mathrm{~b}$ & 27 \\
\hline $\mathrm{R}_{8}$ & $8.1 \mathrm{~b}$ & $37.0 \mathrm{~b}$ & 4.5 & 23.3 & $2,067 \mathrm{~b}$ & 9 \\
\hline $\begin{array}{l}\text { Full cycle unweeded (no } \\
\text { weed control) }\end{array}$ & $8.5 \mathrm{~b}$ & $37.3 \mathrm{~b}$ & 4.4 & 23.0 & $1,890 \mathrm{~b}$ & - \\
\hline \multicolumn{7}{|l|}{ Statistical probability* } \\
\hline $\mathrm{Cu}$ & $\mathrm{p} \leq 0.05$ & $\mathrm{p} \leq 0.01$ & $\mathrm{p} \leq 0.01$ & $\mathrm{p} \leq 0.05$ & $\mathrm{p} \leq 0.05$ & - \\
\hline $\mathrm{Co}$ & $\mathrm{p}>0.05$ & $\mathrm{p}>0.05$ & $\mathrm{p}>0.05$ & $\mathrm{p}>0.05$ & $\mathrm{p}>0.05$ & - \\
\hline $\mathrm{T}$ & $\mathrm{p} \leq 0.05$ & $\mathrm{p} \leq 0.05$ & $\mathrm{p}>0.05$ & $\mathrm{p}>0.05$ & $\mathrm{p} \leq 0.01$ & - \\
\hline $\mathrm{Cu} \times \mathrm{Co}$ & $\mathrm{p}>0.05$ & $\mathrm{p}>0.05$ & $\mathrm{p}>0.05$ & $\mathrm{p}>0.05$ & $\mathrm{p}>0.05$ & - \\
\hline $\mathrm{Cu} \times \mathrm{T}$ & $\mathrm{p}>0.05$ & $\mathrm{p}>0.05$ & $\mathrm{p}>0.05$ & $\mathrm{p}>0.05$ & $\mathrm{p}>0.05$ & - \\
\hline $\mathrm{Co} \times \mathrm{T}$ & $\mathrm{p}>0.05$ & $\mathrm{p}>0.05$ & $\mathrm{p}>0.05$ & $\mathrm{p}>0.05$ & $\mathrm{p}>0.05$ & - \\
\hline $\mathrm{Cu} \times \mathrm{Co} \times \mathrm{T}$ & $\mathrm{p}>0.05$ & $\mathrm{p}>0.05$ & $\mathrm{p}>0.05$ & $\mathrm{p}>0.05$ & $\mathrm{p}>0.05$ & - \\
\hline CV (\%) & 24.1 & 27.8 & 5.9 & 3.9 & 25.9 & - \\
\hline
\end{tabular}


the number of pods per plant rather than any other crop characteristic (Table 3).

In common bean plants, a reduction in number of pods per plant has been related to the species cultivated under stress. Within the stress factors, nutrition, water and light availability are the main causes that may alter this parameter, as these resources are fundamental to the plant development. Arf et al. (2008) and Alvarez et al. (2005) reported that when common bean was cultivated with inadequate nutrition (low nitrogen), a lower number of pods per plant was observed. Miorini et al. (2011) observed that low water availability also resulted in a lower number of pods per plant.

The factors that influenced the number of pods per plant (nutrients and water availability) are also the main resources that weeds compete with a crop for. Therefore, the lower number of pods per plant observed between weeds and crops (Teixeira et al. 2009, Borchartt et al. 2011) may be due to the competition of nutrient and water, as there is a close relation between these factors.

The full cycle weeded (control) and control at the $\mathrm{V}_{4-3}$ stage showed similar yield results, with both being higher than for any other treatment (Table 3).
The full cycle weeded (control) yielded 70\% more than the full cycle unweeded (no weed control), whereas the yield in the groups that had weed control at the $\mathrm{V}_{4-3}, \mathrm{R}_{5}$ and $\mathrm{R}_{8}$ stages were $66 \%, 27 \%$ and $9 \%$ higher, respectively, when compared to the full cycle unweeded (no weed control). Therefore, the weed control at the $\mathrm{V}_{4-3}$ stage can be considered the end of the total period that will allow for prevention of weed interference for early-maturing common bean cultivars. The data also indicates that weed control should not be extended to the $\mathrm{R}_{5}$ stage, in order to avoid yield losses.

These results corroborate those reported by Borchartt et al. (2011), who found that the period for preventing interference in the Carioca Precoce cultivar was up to 18 days after emergence. A similar result has been described by Salgado et al. (2007), which suggest that interference could be prevented until 25 days after emergence, for the Carioca cultivar, reducing the yield to approximately $67 \%$. Kozlowski et al. (2002) reported that the period of coexistence between weeds and common bean plants might occur without yield loss until $\mathrm{V}_{4}$.

With regard to seed physiological potential, results showed that the cultivars did not influence seed germination (Table 4), although differences were

Table 4. Seed moisture content (MC), first germination count (FGC), germination (G), germination speed index (GSI), seed moisture content after accelerated ageing $\left(\mathrm{MC}_{\mathrm{AA}}\right)$, accelerated ageing $(\mathrm{AA})$ and electrical conductivity $(\mathrm{EC})$ for two cultivars, with different types and periods of weed control (Ilha Solteira, SP, 2009).

\begin{tabular}{|c|c|c|c|c|c|c|c|}
\hline \multirow{2}{*}{ Treatment } & $\mathrm{MC}$ & $\mathrm{G}$ & $\mathrm{FGC}^{1}$ & $\mathrm{MC}_{\mathrm{AA}}$ & AA & \multirow{2}{*}{ GSI } & \multirow{2}{*}{$\begin{array}{c}\mathrm{EC} \\
\mu \mathrm{S} \mathrm{cm}^{-1} \mathrm{~g}^{-1}\end{array}$} \\
\hline & \multicolumn{5}{|c|}{$\%$} & & \\
\hline \multicolumn{8}{|l|}{ Cultivars (Cu) } \\
\hline Carioca Precoce & 10.2 & 98 & $86 b^{1}$ & 32.2 & $85 b^{1}$ & $9.2 \mathrm{~b}^{1}$ & $45.1 \mathrm{a}^{1}$ \\
\hline IPR-Colibri & 11.2 & 99 & $95 \mathrm{a}$ & 33.2 & $90 \mathrm{a}$ & $9.7 \mathrm{a}$ & $39.7 \mathrm{~b}$ \\
\hline \multicolumn{8}{|l|}{ Types of weed control (Co) } \\
\hline Chemical & 12.0 & 99 & 91 & 33.0 & 88 & 9.5 & 42.1 \\
\hline Mechanic & 11.5 & 98 & 89 & 32.5 & 87 & 9.4 & 42.7 \\
\hline \multicolumn{8}{|l|}{ Periods of weed control (T) } \\
\hline Full cycle weeded (control) & 10.7 & 99 & 90 & 32.5 & $90 \mathrm{a}^{1}$ & 9.5 & 42.1 \\
\hline $\mathrm{V}_{4-3}$ & 11.2 & 98 & 90 & 33.1 & $90 \mathrm{a}$ & 9.4 & 42.4 \\
\hline $\mathrm{R}_{5}^{4-3}$ & 11.2 & 99 & 90 & 32.5 & $87 \mathrm{ab}$ & 9.5 & 42.1 \\
\hline \multirow{2}{*}{$\begin{array}{l}\mathrm{R}_{8}^{5} \\
\text { Full cycle unweeded (no } \\
\text { control) }\end{array}$} & 10.9 & 98 & 91 & 33.9 & $87 \mathrm{ab}$ & 9.4 & 42.8 \\
\hline & 11.0 & 99 & 91 & 32.7 & $84 \mathrm{~b}$ & 9.5 & 42.4 \\
\hline \multicolumn{8}{|l|}{ Statistical probability* } \\
\hline $\mathrm{Cu}$ & - & $\mathrm{p}>0.05$ & $\mathrm{p} \leq 0.01$ & - & $\mathrm{p} \leq 0.01$ & $\mathrm{p} \leq 0.01$ & $\mathrm{p} \leq 0.01$ \\
\hline $\mathrm{Co}$ & - & $\mathrm{p}>0.05$ & $\mathrm{p}>0.05$ & - & $\mathrm{p}>0.05$ & $\mathrm{p}>0.05$ & $\mathrm{p}>0.05$ \\
\hline $\mathrm{T}$ & - & $\mathrm{p}>0.05$ & $\mathrm{p}>0.05$ & - & $\mathrm{p} \leq 0.05$ & $\mathrm{p}>0.05$ & $\mathrm{p}>0.05$ \\
\hline $\mathrm{Cu} \times \mathrm{Co}$ & - & $\mathrm{p}>0.05$ & $\mathrm{p}>0.05$ & - & $\mathrm{p}>0.05$ & $\mathrm{p}>0.05$ & $\mathrm{p}>0.05$ \\
\hline $\mathrm{Cu} \times \mathrm{T}$ & - & $\mathrm{p}>0.05$ & $\mathrm{p}>0.05$ & - & $\mathrm{p}>0.05$ & $\mathrm{p}>0.05$ & $\mathrm{p}>0.05$ \\
\hline $\mathrm{Co} \times \mathrm{T}$ & - & $\mathrm{p}>0.05$ & $\mathrm{p}>0.05$ & - & $\mathrm{p}>0.05$ & $\mathrm{p}>0.05$ & $\mathrm{p}>0.05$ \\
\hline $\mathrm{Cu} \times \mathrm{Co} \times \mathrm{T}$ & - & $\mathrm{p}>0.05$ & $\mathrm{p}>0.05$ & - & $\mathrm{p}>0.05$ & $\mathrm{p}>0.05$ & $\mathrm{p}>0.05$ \\
\hline $\mathrm{CV}(\%)$ & - & 5.9 & 8.5 & - & 4.9 & 3.1 & 5.7 \\
\hline
\end{tabular}

${ }^{1}$ Means in the same column, followed by the same letter, were not different according to the Tukey test, at $5 \%$. $* \mathrm{p}>0.05$, $\mathrm{p} \leq 0.05$ and $\mathrm{p} \leq 0.01$ are considered nonsignificant and significant at $5 \%$ and $1 \%$, respectively. 
found in seed vigor (assessed by first germination count, germination speed index, accelerated aging and electrical conductivity) (Table 4). In the present study, it is possible that the seeds of the IPR-Colibri cultivar had some substance (antioxidant or lignin) in their seed structure that provided higher vigor because the seeds of both cultivars were harvested in the same conditions. According to Peske et al. (2006), genetic factors may affect seed quality, which can result in differences in species longevity and vigor.

For the period of weed control, it was observed that the full cycle unweeded (no weed control) showed the lowest seed vigor, which was estimated from the accelerated aging test. The best results for seed quality were from the full cycle weeded (control) and control at the $\mathrm{V}_{4-3}$ stage.

Similarly to the observed number of pods per plant and yield, the coexistence between weed and crop reduced the seed vigor. Some studies have shown that seeds have lower vigor when cultivated in soil with low fertility (Nakagawa et al. 2004) and low water availability (Crusciol et al. 2001). Additionally, these factors (nutrients and water) are the main resources that weeds and crops compete for. A lower seed vigor was observed in treatments with later control $\left(\mathrm{R}_{5}, \mathrm{R}_{8}\right.$ and full cycle unweeded).

\section{CONCLUSIONS}

1. The Carioca Precoce cultivar demonstrated higher agronomic performance and yield than the IPRColibri cultivar, although the IPR-Colibri seeds had a higher vigor.

2. The type of weed control (chemical or mechanic) did not affect the agronomic characteristics, yield and seed physiological potential of the cultivars.

3. The ideal period for weed control in early-maturing common bean cultivars to obtain higher yield and seed physiological potential was the $\mathrm{V}_{4-3}$ stage.

\section{ACKNOWLEDGMENTS}

We thank Marcos A. N. Dias and John A. Winder for their valuable corrections of the English version of the manuscript. The first author thanks the FAPESP (São Paulo State Research Foundation) for the scholarship grant.

\section{REFERENCES}

ALVAREZ, A. C. C. et al. Resposta do feijoeiro à aplicação de doses e fontes de nitrogênio em cobertura no sistema de plantio direto. Acta Scientiarum Agronomy, Maringá, v. 27, n. 1, p. 69-75, 2005.

AMBROSANO, E. J. et al. Feijão. In: RAIJ, B. V. et al. (Orgs.). Recomendações de adubação e calagem para o Estado de São Paulo. 2. ed. Campinas: Instituto Agronômico, 1997. p. 189-195. (Boletim técnico, 100).

ARF, O. et al. Mecanismos de abertura do sulco e adubação nitrogenada no cultivo do feijoeiro em sistema plantio direto. Bragantia, Campinas, v. 67, n. 2, p. 499-506, 2008.

BAALBAKI, R. et al. Seed vigor testing handbook. Ithaca: AOSA, 2009.

BORCHARTT, L. et al. Períodos de interferência de plantas daninhas na cultura do feijoeiro-comum (Phaseolus vulgaris L.). Revista Ciência Agronômica, Fortaleza, v. 42, n. 3, p. 725-734, 2011.

BRASIL. Ministério da Agricultura, Pecuária e Abastecimento. Secretaria de Defesa Agropecuária. Regras para análise de sementes. Brasília, DF: MAPA, 2009.

CHRISTOFFOLETI, P. J.; LÓPEZ-OVEJERO, R. F.; NICOLAI, M. Manejo racional de plantas daninhas na cultura de feijão. In: FANCELLI, A. L.; DOURADONETO, D. (Eds.). Feijão irrigado: tecnologia e produção. Piracicaba: ESALQ, 2005. p. 29-42.

COORDENADORIA DE ASSISTÊNCIA TÉCNICA INTEGRAL (CATI). Feijão carioca precoce: catálogo. Campinas: CATI, 1997.

CRUSCIOL, C. A. C. et al. Produção e qualidade fisiológica de sementes de arroz de terras altas em função da disponibilidade hídrica. Revista Brasileira de Sementes, Pelotas, v. 23, n. 2, p. 287-293, 2001.

CURY, J. P. et al. Eficiência nutricional de cultivares de feijão em competição com plantas daninhas. Planta Daninha, Viçosa, v. 31, n. 1, p. 79-88, 2013.

EMPRESA BRASILEIRA DE PESQUISA AGROPECUÁRIA (Embrapa). Centro Nacional de Pesquisa em Solos. Sistema brasileiro de classificação de solos. Brasília, DF: Embrapa-SPI; Rio de Janeiro: Embrapa-Solos, 2006.

FERREIRA, D. F. Sisvar: um programa para análises e ensino de estatística. Revista Symposium, Lavras, v. 6, n. 1, p. 36-41, 2008.

FERREIRA, F. A. et al. Manejo de plantas daninhas. In: VIEIRA, C.; PAULA JÚNIOR, T. J.; BORÉM, A. (Eds.). 2. ed. Feijão.Viçosa: UFV, 2006. p. 309-340. 
HERNANDES, F. B. T.; LEMOS FILHO, M. A. F.; BUZETTI, S. Software Hidrisa e o balanço hídrico de Ilha Solteira. Ilha Solteira: Unesp, 1995. (Irrigação, 1).

INSTITUTO AGRONÔMICO DO PARANÁ (Iapar). Cultivar de feijão IPR Colibri: catálogo. Londrina: Iapar, 2004.

JADOSKI, S. O. et al. População de plantas e espaçamento entre linhas do feijoeiro irrigado: I - comportamento morfológico das plantas. Ciência Rural, Santa Maria, v. 30, n. 4, p. 559-565, 2000.

KOZLOWSKI, L. A. et al. Período crítico de interferência das plantas daninhas na cultura do feijoeiro-comum em sistema de semeadura direta. Planta daninha, Viçosa, v. 20, n. 2, p. 213-220, 2002.

LORENZI, H. Manual de identificação e controle de plantas daninhas. 6. ed. Nova Odessa: Instituto Plantarum, 2006.

MAGUIRE, J. D. Speed of germination-aid in selection and evaluation for seedling emergence and vigor. Crop Science, Madison, v. 2, n. 1, p. 176-177, 1962.

MIORINI, T. J. J.; SAAD, J. C. C.; MENEGALE, M. L. Supressão de água em diferentes fases fenológicas do feijoeiro. Irriga, Botucatu, v. 16, n. 4, p. 360-368, 2011.

NAKAGAWA, J.; CAVARIANI, C.; CASTRO, M. M. Armazenamento de sementes de aveia preta produzidas em solos de diferentes fertilidades. Revista Brasileira de Sementes, Pelotas, v. 26, n. 1, p. 7-14, 2004.

PEREIRA, M. C. et al. Modeling of weeds interference periods in bean. Planta Daninha, Viçosa, v. 30, n. 4, p. 713-720, 2012.
PESKE, S. T.; LUCCA FILHO, O. A.; BARROS, A. C. S. A. (Eds.). Sementes: fundamentos científicos e tecnológicos. 2. ed. rev. e ampl. Pelotas: UFPel, 2006. p. $140-224$.

RADOSEVICH, S. R.; HOLT, J. S. Weed ecology: implications for vegetation management. New York: John Wiley \& Sons, 1984.

SALGADO, T. P. et al. Interferência das plantas daninhas no feijoeiro carioca. Planta Daninha, Viçosa, v. 25, n. 3 , p. 443-448, 2007.

SCHOLTEN, R. et al. Período anterior à interferência das plantas daninhas para a cultivar de feijoeiro 'Rubi' em função do espaçamento e da densidade de semeadura. Acta Scientiarum Agronomy, Maringá, v. 33, n. 2, p. 313320, 2011.

SOIL SURVEY STAFF (SSS). Keys to soil taxonomy. 11. ed. Washington, DC: USDA, 2010.

TEIXEIRA, I. R. et al. Competição entre feijoeiros e plantas daninhas em função do tipo de crescimento dos cultivares. Planta Daninha, Viçosa, v. 27, n. 2, p. 235240, 2009.

VIEIRA, R. D.; KRZYZANOWSKI, F. C. Teste de condutividade elétrica. In: VIEIRA, R. D.; KRZYZANOWSKI, F. C.; FRANÇA NETO, J. B. Vigor de sementes: conceitos e testes. Londrina: Abrates,1999. p. 4.01-4.20. 